\title{
Mediating Patriotism and Triumph through the National Press: Newspaper Content and Journalistic Perceptions
}

\author{
Theodora A. Maniou ${ }^{1}$, Irene Photiou ${ }^{1} \&$ Elena Ketteni ${ }^{2}$ \\ ${ }^{1}$ Department of Journalism, Frederick University of Cyprus. \\ ${ }^{2}$ Department of Business Administration, Frederick University of Cyprus. \\ Correspondence: Dr. Theodora A. Maniou, Department of Journalism, Frederick University, Nicosia, 7, Y. Frederickou \\ str, 1036, Cyprus.
}

Received: April 5, 2016

doi:10.11114/ijsss.v4i6.1588
Accepted: April 29, 2016

Available online: May 3, 2016

\begin{abstract}
Patriotism and triumph are directly affiliated to historical memories and to every country's history, since every nation / society's need to proclaim its national achievements in every aspect of daily life, from politics to economy, science and beyond. Following several countries' turbulent history, since their origins, traditionally the media tend to express the feeling of patriotism that overwhelms the local society. In this perspective, patriotism and triumph concerning national achievements seem to be among the traditional characteristics in the journalistic content of the press. However, although evident in the media content, it is not yet identified in what extend they exist and through which characteristics. This papers addresses these two issues in the content of the current national press in Cyprus, aiming to examine the specific characteristics of patriotism and triumph and the extend up to which they are evident today in the journalistic practices. Taking into account the loyal - facilitator model of journalism, the research is based both on content analysis of the national newspapers with the higher circulation and on a survey concerning the journalists' opinion that work for these newspapers. The sample of content analysis includes an extensive number of news items, since the research was conducted in a two years period of time, while more than two thirds of the journalists working in these newspapers participated in the survey. The aim of this paper is to clarify whether the national press remains attached to practices of the past or new modes of journalism have arisen.
\end{abstract}

Keywords: Patriotism, national triumph, press, newspapers, journalists, Cyprus

\section{Introduction}

Patriotism and triumph are directly affiliated to historical memories and to every country's/ nation's turbulent history. Following every country's history, since their origins, traditionally the media tend to express the feeling of patriotism, especially in times of crisis. As Waisbord (2002, p.273) argues 'to provide comfort to a grieving, shocked society...the media rely on a well-known nationalistic scope: a shared, national culture provides solace and unity to a community that suffers'. In this perspective, patriotism and triumph concerning national achievements seem to be among the traditional characteristics in the journalistic content of the press. However, although evident in the media content, it is not yet identified in what extend they exist and through which characteristics. This papers addresses these two issues in the content of the current national press, aiming to examine the specific characteristics of patriotism and triumph and the extend up to which they are evident today in the journalistic practices.

In this perspective, taking into account the loyal facilitator model of the press, this paper assesses the issue of patriotism and its specific types that are represented through the press, especially in times of crisis. As such, Cyprus was selected as a country in crisis during the years 2012 and 2013, when the banking crisis arose. The research is based both on content analysis of the national newspapers and on a survey concerning the journalists' opinion that work for these newspapers. The aim of this paper is to clarify whether the press remains attached to practices of the past or new modes of journalism have arisen.

\subsection{Literature review: Journalistic roles and the loyal facilitator model}

Journalists and their roles in society have changed considerably during the past few decades, with the advent of the internet and the immediacy of smart technologies. Nevertheless, as the 'fourth estate,' they still seem to fulfil certain 
diachronic social duties in the ever-shifting contemporary society, in their effort to preserve their traditional audience (Maniou, 2013). Denis McQuail (2006, pp. 55-56) identifies (at least) four such roles. First, they have a 'monitorial' mission to observe the local as well as international players related to their own community, to discover, analyze and report news, arising from a multiplicity of sources, in an impartial and trustworthy manner, and to announce events deemed important to their public. This is also called the 'watchdog' model of journalism (Mellado \& Van Dalen, 2013). These tasks are to be achieved following an agenda they are responsible in establishing. Second, journalists are expected to 'facilitate' the dialog between the civil society and the government, encouraging the establishment of community and the participation of private citizens in it and its dialog with the local powers (McQuail, 2006, p. 56). This is referred to as the 'civic-oriented' model of journalism (Mellado \& Van Dalen, 2013). Their third and more rare role is 'collaborative.' In this, they are expected to forgo profit and their journalistic purpose of investigating the political powers, and instead to collaborate with authorities and other agencies, even the government, during times when the greater needs of society take precedence (such as, in times of natural disaster, threat or similar crisis). Finally, a fourth, but not mainstream, task is to be 'radical' in their public criticism; that is, this role often necessitates journalists to assume a conspicuously antagonistic stance, beyond the limited, 'professional' journalistic commentary, against some social elite or power structure in favour of a victimized group (McQuail, 2006, pp. 55-56; see also, Downing, 2000).

This work will focus on the use of the loyal facilitator model of journalism, a journalistic paradigm arising from the third aforementioned function (Mellado \& Van Dalen, 2013; see also, Mellado, 2014). In this, the ideals and/or interests of various powerful elites are promoted in one of two versions. In one variant, journalists collaborate with said powerful elite in order to protect an existing state of affairs. To do so, the news depict a positive image of said group(s), by backing 'institutional activities' and promoting 'national policies' (Mellado \& Van Dalen, 2013, pp. 4, 19-20). In the other type, journalism 'moves the focus from the de facto powers to the nation-state unit,' thereby endorsing the feeling of being part of a country and reinforcing the prestige of said nation-state. In order to promote nationalistic tendencies in this way, journalists highlight the 'country's progress and/or success, compare the country/region to the rest of the world,' embellish the triumphs of citizens/nationals and 'include patriotic elements' in the news (ibid).

\section{Representation of patriotism, national triumph and achievements in the press}

Since the use of the loyal facilitator model hinges on public perceptions of patriotism, in this section we define this term and examine its representations in the media. Although always associated with love for one's country above all others (e.g., Primoratz, 2015), the definition of patriotism we subscribe to in this work reveals it in greater detail than this simple sentiment denotes. It is adopted from the work of Stephen Nathanson (1993, pp. 34-35), which involves four key components. Although love of one's country is paramount, patriotism must also incorporate a feeling of being personally connected with the country; i.e., a person who defines themselves as a patriot derives some significant part of their identity in relation to the country. Furthermore, patriotism is characterized by a regard for the perceived welfare of the country that should run deeply enough for the existence of a will to sacrifice (parts of) oneself in order to defend or enhance this prosperity (see also Primoratz, 2015).

The term patriotism is often used interchangeably with nationalism. Nationalism can be described as national emotion and values formed in the struggle of a nation for its own interests, dignity and future (Zhang, 2014, p.65). In the work of Benedict Anderson (1983, p. 15), a nation is defined as an 'imagined community,' each member of which will never interact with or even meet most other members. Therefore, all members have only a conceptual notion of their shared cultural values and axioms; i.e., their sense of belonging is only in their imaginations (see also Lewis, 2008, pp. 416-417). According to the work of Anderson (1983) and, to a greater extent, Michael Billig (1995, pp. 6-18), the press (and media) play a foundational role in establishing nationalism in an 'imagined community,' and not only as a form of an extreme reaction to specific events, but in fact as a daily occurrence (see, for example, Yumul \& Özkirimli, 2000). The common practice of reporting the news is nation-centric. For example, the media present the in-group in the form of 'us' and others as 'them' and refer to 'here' for the home country versus 'there' for others (ibid, pp. 787-788). This often is referred to as patriotism in the media, but the daily reporting of the news amounts to a promotion of subconscious, even naturalized, nationalism, which Billig (1995) refers to as 'banal nationalism.' Therefore, we recognize that nationalism is not an extreme occurrence in itself, but a routine part of news reporting; perhaps, the only extreme is when it becomes so ingrained that it leads to intolerance and war.

In this work, we distinguish the two terms somewhat differently to the above research. This is not to say that we do not acknowledge the existence of nationalism in the media of any country, or its frequent concealment in references to patriotism. However, since we will be investigating the content of the media of a particular country (Cyprus) as a case study and the opinions of journalists themselves (see below), we can only refer to instances of nationhood and national triumph as patriotism. Thus, we need to distinguish the two terms in greater detail. Following the definition of Igor Primoratz (2015), we do so by decoupling the concept of a nation from that of a country: we use the term nation to comprise the ethnic and cultural features of a community or group (an 'imagined community,' as defined by Anderson 
1983), while the term country maintains it usual geographic and political essence. In this respect, both patriotism and nationalism can be defined as 'love of, identification with, and special concern for' and sacrifice for a specific subject, for the former one's country, while for the latter one's nation. In the (significant number of) distinct countries superposed with nations, there is a vague (if any) differentiation between the two terms (see below). However, in multi-ethnic countries, such as Cyprus, ${ }^{1}$ or communities without countries that are, nonetheless, culturally and ethnically linked, the two terms are distinct (Primoratz, 2015).

\subsection{Types of patriotism: Nationalistic patriotism}

Here, we describe three types of patriotism: nationalistic, constitutional and civic. Due to the overlap of nations and countries, the most common and recognizable form is what we dub nationalistic patriotism. In times of crisis ${ }^{2}$ (e.g., terrorism, war, political and financial crisis), where uncertainty and/or violence are increasingly manifest, and may result in changing ethnic and cultural norms, it is common to perceive the chaos and risk as threats on the nation. Perhaps this is a type of defence mechanism: this perception gives the members of a nation support, a common ground against said changes, even a common asset, the nation itself, for all to protect (Waisbord, 2002, pp. 214-215). When the nation consists of the totality, or majority, of citizens within a country, these sentiments often lead to nationalistic patriotism, particularly as a means of individual survival and sense of purpose within a larger whole. Nevertheless, this kind of 'my-country-above- everything' patriotism may, and frequently does, lead to intolerance and (racial) hatred, even violence and conquest (ibid).

Nationalistic patriotism often provides a balm for the finances and assertion of social and cultural relevance of the native media. In return, said media represent national achievement as triumph, defending patriotism as virtuous and perpetuating nationalistic propaganda. Such representations abound plentifully. For example, the coverage of sports in European media is affluent with references to national triumph and a sense of patriotic pride, akin to going to war; a striking instance is the reporting of European football championships in the Dutch national press (Moshe \& Lehman-Wilzig, 2006). Another case of perceived national triumph from newsworthy sports is the choice of George W. Bush to be surrounded by the 1980 US hockey team, which had upset the Soviet team in those games, when declaring open the 2002 Winter Olympics at the opening ceremony at Salt Lake City, 'on behalf of a proud, determined and grateful nation' (Kellner, 2003). Perhaps the most striking journalistic representation of nationalistic patriotism has been the US media coverage during the weeks after the $9 / 11$ attacks, as most adhered to the official government line and propaganda regarding the terrorist attacks, deferring to no other sources (Eisman, 2003, pp. 11-12, see also Altheide, 2004; Waisbord, 2002). Finally, in depicting the (second) Iraq war, British newspapers (even the ones against it) exhibited their patriotism by reporting on daily events and news from battles, highlighting the need to support the troops and their families, rather than question the need for war (Goddard, Robinson \& Parry, 2008, p. 27; see also, Aday, Livingston \& Herbert, 2005, p. 18; Lewis, Brookes, Mosdell \& Threadgold, 2006, p. 114).

\subsection{Civic Patriotism}

Civic patriotism, as defined by Silvio Waisbord (2002, p. 215; see also Ignatieff, 1999), is a gentler, more progressive form of nationalism-related patriotism. Specifically, while it still promotes camaraderie with, empathy for and service towards one's country and its other citizens, it also encourages acceptance, egalitarianism and respect of the democratic ethos. That is, it is a type of multicultural patriotism within a single country (Shabani, 2002; see also Moshe, 2004). It is believed to be practiced, for example, in some strata of the American society and is frequently preferred to its more severe cousin (Barber, 1996; Rorty, 1998).

\subsection{Constitutional Patriotism}

Finally, Jurgen Habermas (1996) proposes a new paradigm for patriotism, which he refers to as constitutional, to replace the pending loss of country, since the power of the nation-state is gradually waning to a simple administrative influence. Foremost in this model is the adherence to rational principles, such as the law, for definition of self and national identity, instead of allegiance to a territory, history or political system. In this model, patriotic duty would be to follow the constitution, pride would result from a successful democracy, and human connections would result from a shared acquiescence to the law rather than political, economic or other motivations. Thus, it would diminish the need

\footnotetext{
1 Although statistics regarding the ethnicity of the population in Cyprus have been a bit sketchy since 1974 (due to the Turkish invasion that split the island into two regions), at that time it was estimated that $85 \%$ of the population were of Greek-Cypriot origin, $12 \%$ were Turkish-Cypriots, and the Armenian, Latin and other Catholic groups comprised the remaining 3\% of the population (PIO, 2000: 50). Often, patriotism in the media of the Greek-Cypriot community amounts to being against Turkish interests, while the reverse also is true in the media of the Turkish-Cypriot community.

${ }^{2}$ We adhere to the definition of crisis as an unforeseen event that upsets the usual functional processes within a society, resulting in an ambiguous and constantly varying situation, the consequences of which are difficult to predict (Coombs, 1999).
} 
for nationalism and promote a universal world-view (Habermas, 1996; see also Moshe, 2004). This version of patriotism is far from being endorsed by commercial media, however, even those that figure as proponents for it. For example, although encountered in the Israeli financial newspaper Globes during times of non-violence, anti-Israeli terror attacks seem to stimulate demonstrations of civic and nationalistic patriotism in the newspaper, with such attacks and anti-US terror attacks causing it to revert to a nationalistic patriotism altogether (Moshe, 2004, pp. 505-506).

\section{RQs and Scope of Study}

This study addresses the issues of patriotism and triumph in the content of the current Cypriot press, aiming to examine the specific characteristics of them and the extend up to which they are evident today in the journalistic practices. Taking into account the loyal - facilitator model of journalism, the research is based both on content analysis of the five national newspapers with the higher circulation and on a survey concerning the opinions of the journalists who work for these newspapers. The sample of content analysis includes an extensive number of news items, since the research was conducted in a two year period, while the majority of the journalists working in these newspapers participated in the survey.

The aim of the study is to clarify whether the national press remains attached to practices of the past or new modes of journalism have arisen. The research is based on the following Research Questions:

RQ1: To what extend patriotism and national triumph are evident in the national press?

RQ2: Which characteristics of the loyal facilitator model of the press are evident in the Greek- Cypriot press and to what extend?

RQ3: To what extend journalists in Cyprus realize that patriotism and triumph are evident in their work?

RQ4: Does the perception of journalists for the content of their work reflects the true picture of the content of newspapers?

\section{Research Methodology}

The research is based on quantitative Formal Content Analysis of the news items (reportages), including assorted elements (photographs, figures, etc.), in which a systematic sample of texts is used. For the Content Analysis, classification systems were devised to identify different features of the texts, which were then counted with an emphasis on objectivity and reliability (Pawson, 1995). The data reported in this article derive from the Content Analysis of the national Greek-Cypriot press in the years 2012 and 2013, as part of a broader ongoing research project concerning journalistic role models in Cyprus ${ }^{3}$. The sample of newspapers was selected every month of 2012 and 2013 following a simple mathematical sequence, based on the days of the week. The unit of the analysis was the news item, defined as a single, continuous text comprising of lexical elements and accompanying non-verbal features (such as tables, images, etc.) in the same news item and concerning the same subject matter (Mellado \& Lagos, 2014, p. 2095). Specific criteria on the form and visual presentation of each reportage were not set a-priori, as the intention was to include as many units of analysis as possible in the research. In this framework, the research sample consists of units of analysis from the five newspapers with the highest circulation for 2012 and 2013; those are the following newspapers: PHILELEFTHEROS, POLITIS, SIMERINI, CHARAVGI and ALITHIA ${ }^{4}$. Among the newspapers included in the sample, PHILELEFTHEROS and POLITIS are considered mainstream, ALITHIA and SIMERINI are considered neo-liberal, while CHARAGI is the formal medium of the left-wing party AKEL (PRIO group, 2010, p. Appendix I). The final sample comprises of 2012 reportages, as presented in Table 1 below.

Table 1. The total news items sample of the research

\begin{tabular}{lccc}
\hline Newspaper & 2012 & 2013 & Total \\
\hline ALITHIA & 192 & 189 & 381 \\
CHARAVGI & 206 & 274 & 480 \\
PHILELEFTHEROS & 124 & 234 & 358 \\
POLITIS & 113 & 318 & 431 \\
SIMERINI & 196 & 166 & 362 \\
Total & 831 & 1181 & $\mathrm{n}=2012$ \\
\hline
\end{tabular}

\footnotetext{
3 This research is part of a larger research project, entitled 'Journalistic Role Performance around the Globe' (JRP), which has been used to investigate journalistic role performances in 33 participating countries (http://www.journalisticperformance.org/ , @ Jourperformance ).

${ }^{4}$ http://www.sigmalive.com/inbusiness/news/services/118037.
} 
In the course of the study, seven researchers were trained in the implementation process of a particular codebook, while a pre-test and a post-test were conducted to ensure that the researchers comprehended in a similar manner the additional variables (Mellado \& Lagos, 2014, pp. 2095-2096). The tests yielded overall inter-coder reliability 0.89 (pre-test) and 0.93 (post-test) employing the KRIPPENDORFF's ALPHA test.

Furthermore, the second level of this research included a questionnaire survey on the specific journalists that reported the specific news items measured in the content analysis, in order to examine their personal beliefs and their daily practices regarding patriotism. The total journalists sample ${ }^{5}$ is presented in Tables 2, 3 and 4.

Based on Tables 2-4, the questionnaire was administered to 48 journalists of different gender, age and political beliefs. Specifically, we have 22 males and 26 females. $27.1 \%$ of the sample is in the age group $20-29$ and $40-49,29.2 \%$ in the 30 to 39 group and $16.6 \%$ in the above 50 years old. Finally, $39.2 \%$ of the journalist stated that their political beliefs are left or towards left, $25 \%$ center-oriented and $35.8 \%$ right or towards right. Based on these characteristics, we believe that this sample is well distributed.

Table 2. Journalists' sample

\begin{tabular}{ccc}
\hline & $\mathrm{N}$ & $\%$ \\
\hline Males & 22 & 46 \\
Females & 26 & 54 \\
Total & 48 & 100 \\
\hline
\end{tabular}

Table 3. Journalists' Age

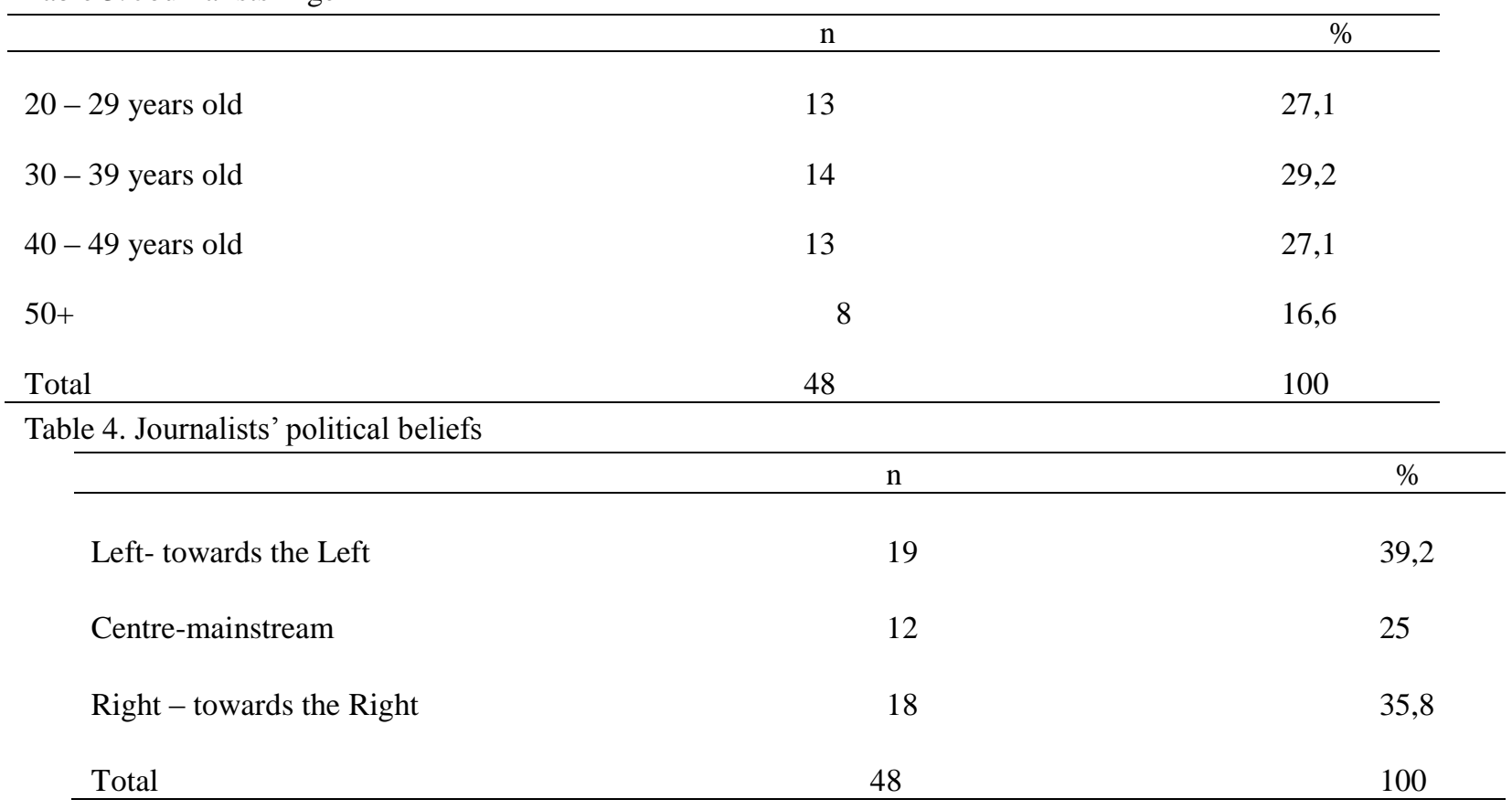

\section{Findings and Discussion}

Taken under consideration the basic characteristics of the loyal facilitator model of the press, as analyzed in the theoretical framework, this study initially examined the extend up to which these characteristics of patriotism and national triumph are evident in the national press. In this perspective, Table 5 shows that only 4,1\% of the news items include references to national triumphs, $7,8 \%$ of them tend to promote the country's image, while only $14,6 \%$ of the news items show patriotism. All descriptive statistics were tested with a chi square test (goodness of fit), which verified the findings. The specific chi-square test examines whether the percentages (frequencies) found in the data are valid and

\footnotetext{
5 It has to be noted that national newspapers in Cyprus are small editions - no more than 50 pages in the daily editions - occupying limited number of journalists, 8-10 average per newspaper. This is why the number of the journalists sample is limited to 48 .
} 
correct.

Table 5. Characteristics of patriotism in the newspapers' content

\begin{tabular}{|c|c|c|c|c|}
\hline & No & Yes & Total & Goodness test \\
\hline $\begin{array}{l}\text { Reference to national } \\
\text { triumphs in the news } \\
\text { items }\end{array}$ & $95,9 \%$ & $4,1 \%$ & $100 \%$ & $\mathrm{p}=0.000$ \\
\hline $\begin{array}{l}\text { Promotion of the } \\
\text { country's image }\end{array}$ & $92,2 \%$ & $7,8 \%$ & $100 \%$ & $\mathrm{p}=0.000$ \\
\hline Patriotism & $85,4 \%$ & $14,6 \%$ & $100 \%$ & $\mathrm{p}=0.000$ \\
\hline $\begin{array}{l}\text { Comparison to the rest } \\
\text { of the world }\end{array}$ & $87,7 \%$ & $12,3 \%$ & $100 \%$ & $\mathrm{p}=0.000$ \\
\hline
\end{tabular}

An important factor that plays a key role in the tendency on behalf of the newspapers to present patriotism and reference to national triumphs, is the topic in which the news items are referring to (such as government, campaigns, police and crime, defense, economy, education, environment, transportation, housing health, religion, human rights, social problems and others). The chi-square test of independence shows that there is a correlation (relationship) between item topic and the two concepts. Specifically, the correlation shows that patriotism and national triumphs are evident in news items and especially in between items referring to the country's economy and to political issues as indicated by their high frequencies as presented in Table 6 (16.3\% of economic items and $9.9 \%$ of government/legislative refer to patriotism, while $1.2 \%$ of defense, national security or military items refer to national triumphs). Although, we would expect that in a country like Cyprus (after the Turkish invasion and the territorial division between North and South), news items referring to defense/national security/military topics would have shown extremely high frequency of patriotism, the analysis shows no evidence of such a case. Additionally, there is a significant positive correlation between item topic and the country's comparison to the rest of the world.

Table 6. Correlation between news items with elements of patriotism/triumphs/comparison and news items' topic

\begin{tabular}{|c|c|c|c|c|c|c|c|}
\hline & \multicolumn{2}{|c|}{ Patriotism } & \multirow{2}{*}{$\begin{array}{l}\text { Reference } \\
\text { triumphs } \\
\underline{\text { Yes }}\end{array}$} & \multirow[t]{2}{*}{ to } & \multirow{2}{*}{$\begin{array}{c}\text { national } \\
\underline{\text { No }}\end{array}$} & \multicolumn{2}{|c|}{$\begin{array}{l}\text { Comparison to the rest of } \\
\text { the world }\end{array}$} \\
\hline & $\underline{\text { Yes }}$ & $\underline{\text { No }}$ & & & & Yes & No \\
\hline Government/legislatures & $9,9 \%$ & $12,5 \%$ & $0,4 \%$ & & $13 \%$ & $1,6 \%$ & $11.8 \%$ \\
\hline Campaigns/elections/politics & $0,9 \%$ & $9,4 \%$ & $0,2 \%$ & & $10,1 \%$ & $0,5 \%$ & $9,8 \%$ \\
\hline Police and crime & $0,2 \%$ & $7,7 \%$ & $0 \%$ & & $7,9 \%$ & $0,3 \%$ & $7.6 \%$ \\
\hline Court & $0,5 \%$ & $6,1 \%$ & $0 \%$ & & $6,6 \%$ & $0,2 \%$ & $6,4 \%$ \\
\hline Defense/nat.security/military & $4 \%$ & $2,8 \%$ & $1,2 \%$ & & $5,6 \%$ & $1,4 \%$ & $5,4 \%$ \\
\hline Economy & $16,3 \%$ & $3,4 \%$ & $0 \%$ & & $19 \%$ & $3,3 \%$ & $16,4 \%$ \\
\hline Education & $0,3 \%$ & $4 \%$ & $0,2 \%$ & & $4,1 \%$ & $0,2 \%$ & $4,1 \%$ \\
\hline Energy/environment & $0,9 \%$ & $3,6 \%$ & $0,4 \%$ & & $4,1 \%$ & $1 \%$ & $3,5 \%$ \\
\hline Transportation & $0,4 \%$ & $1,2 \%$ & $0,1 \%$ & & $1,5 \%$ & $0,3 \%$ & $1,3 \%$ \\
\hline Housing/infrastructure & $0,5 \%$ & $3 \%$ & $0.1 \%$ & & $3,4 \%$ & $0,1 \%$ & $3,4 \%$ \\
\hline Accidents/natural disasters & $0,1 \%$ & $1,4 \%$ & $0,1 \%$ & & $1,5 \%$ & $0,1 \%$ & $1,4 \%$ \\
\hline Health & $0,4 \%$ & $4,5 \%$ & $0,1 \%$ & & $4,8 \%$ & $0,9 \%$ & $4 \%$ \\
\hline
\end{tabular}




\begin{tabular}{|c|c|c|c|c|c|c|}
\hline Religion/church & $0,2 \%$ & $0,2 \%$ & $0 \%$ & $0,4 \%$ & $0 \%$ & $0,4 \%$ \\
\hline Human rights & $0,4 \%$ & $1,1 \%$ & $0 \%$ & $1.4 \%$ & $0,2 \%$ & $1,3 \%$ \\
\hline Demonstration/protests & $0,1 \%$ & $1,8 \%$ & $0.1 \%$ & $1,8 \%$ & $0 \%$ & $1,9 \%$ \\
\hline Social problems & $0,5 \%$ & $3,1 \%$ & $0 \%$ & $3,6 \%$ & $0,9 \%$ & $2,7 \%$ \\
\hline Other & $0,5 \%$ & $6,7 \%$ & $0,4 \%$ & $6,9 \%$ & $0,9 \%$ & $6,4 \%$ \\
\hline Significance & $x^{2}=$ & & & & & \\
\hline
\end{tabular}

Another important factor in order to estimate the level of patriotism imported in the news items is balanced reporting. In order to quantify balanced reporting, we set and measured three categories of news items: the ones that present total absence of news sources, the ones that are based on unilateral coverage of the news and the ones that are based on different news sources. A test among those factors shows that there exists significant dependence between balanced reporting and reference to national triumphs. As shown by the frequencies in Table 7, most of the news items are based on unilateral coverage (3\%). However, while there are indications that identical relationship could exist between balanced reporting and patriotism, there is no such case, although - again - most of the items are based on unilateral coverage of the news $(8,3 \%)$.

Table 7. Correlation between news items with elements of patriotism/triumph and characteristics of balanced reporting

\begin{tabular}{|c|c|c|c|c|}
\hline & \multicolumn{2}{|c|}{ Patriotism } & \multicolumn{2}{|c|}{ Reference to national triumphs } \\
\hline & $\underline{\text { Yes }}$ & $\underline{\text { No }}$ & $\underline{\text { Yes }}$ & $\underline{\text { No }}$ \\
\hline Absence of sources & $0,8 \%$ & $10,2 \%$ & $0,2 \%$ & $10,08 \%$ \\
\hline Unilateral coverage & $8,3 \%$ & $44 \%$ & $3 \%$ & $49,4 \%$ \\
\hline $\begin{array}{l}\text { Presence of different } \\
\text { sources }\end{array}$ & $5,4 \%$ & $31,2 \%$ & $0,9 \%$ & $35,7 \%$ \\
\hline Significance & \multicolumn{2}{|c|}{$\mathrm{p}=0.600$} & \multicolumn{2}{|c|}{$\begin{array}{c}\mathrm{p}=0.001 \\
\mathrm{x}^{2}=13.835, \mathrm{df}=2\end{array}$} \\
\hline
\end{tabular}

On the other hand, news items comparing national achievements to the rest of the world present no significance correlation to balanced reporting and the same stands for news items promoting the country's image as indicated by the chi-square test. Although there were indications that could exist correlation between these two factors and balanced reporting, due to identical descriptive findings with the existence of patriotism and national triumphs, there exist no such evidence, as shown in Table 8.

Table 8. Correlation between news items that promote the country's image/comparison to other countries and characteristics of balanced reporting

\begin{tabular}{|c|c|c|c|c|}
\hline & \multicolumn{2}{|c|}{ Promotion of country's image } & \multicolumn{2}{|c|}{ Comparison to the rest of the world } \\
\hline & $\underline{\text { Yes }}$ & $\underline{\underline{\text { No }}}$ & $\underline{\text { Yes }}$ & $\underline{\underline{\text { No }}}$ \\
\hline Absence of sources & $1 \%$ & $10,1 \%$ & $1,2 \%$ & $9,8 \%$ \\
\hline Unilateral coverage & $4,5 \%$ & $47,8 \%$ & $6,7 \%$ & $45,7 \%$ \\
\hline Presence of different sources & $2,3 \%$ & $34,3 \%$ & $4,4 \%$ & $32,2 \%$ \\
\hline Significance & \multicolumn{2}{|c|}{$\begin{array}{c}\mathrm{p}=0.141 \\
\mathrm{x}^{2}=3.919, \mathrm{df}=2\end{array}$} & \multicolumn{2}{|c|}{$\begin{array}{c}\mathrm{p}=0.778 \\
\mathrm{x}^{2}=0.502, \quad \mathrm{df}=2\end{array}$} \\
\hline
\end{tabular}

In order to explain the above mentioned findings, we conducted a questionnaire survey on the specific journalists that reported the news items measured in the analysis above. This survey was deemed essential, in order to clarify whether the national press in Cyprus remains attached to practices of the past or new modes of journalism have arisen. In this perspective, journalists in Cyprus seem to consider important in their daily practices to report facts concerning national achievements and expressing positive feelings for these achievements in their stories. As Table 9 shows, there is significant positive correlation as indicated by the Pearson correlation coefficient between what journalists believe 
about expressing positive feelings for news/facts/elements being from own country in their news stories and actually being able to do so in their daily practice ( $p=0.000, r=0.688$ ). In fact, $35,8 \%$ of the journalists working in the national newspapers consider extremely important to express positive feelings for news/facts, etc., being from Cyprus, while $37,7 \%$ of them state that this constitutes a very common daily practice for them. Only $7,5 \%$ and $9,4 \%$ respectively consider them not important and not common at al.

Table 9. Correlation between journalists' desire to express positive feelings for locality and being able to express them in the daily practice

\begin{tabular}{|c|c|c|c|c|c|c|c|}
\hline & $\begin{array}{l}\text { Not important } \\
\text { at all/ Not } \\
\text { common at al }\end{array}$ & $\begin{array}{l}\text { Not very } \\
\text { important/ Not } \\
\text { common }\end{array}$ & $\begin{array}{l}\text { Somewhat } \\
\text { important/ } \\
\text { Sometimes }\end{array}$ & $\begin{array}{l}\text { Very } \\
\text { important/ } \\
\text { Common }\end{array}$ & $\begin{array}{l}\text { Extremely } \\
\text { important/ } \\
\text { Very common }\end{array}$ & $\begin{array}{l}\text { Missing } \\
\text { cases }\end{array}$ & Total \\
\hline $\begin{array}{l}\text { Importance of } \\
\text { expressing } \\
\text { positive feelings } \\
\text { about being from } \\
\text { own country in } \\
\text { his/her news } \\
\text { stories }\end{array}$ & $7,5 \%$ & $15,1 \%$ & $11,3 \%$ & $20,8 \%$ & $35,8 \%$ & $9,4 \%$ & $100 \%$ \\
\hline $\begin{array}{l}\text { Being able to } \\
\text { express positive } \\
\text { feelings about } \\
\text { being from own } \\
\text { country in his/her } \\
\text { news stories }\end{array}$ & $9,4 \%$ & $9,4 \%$ & $9,4 \%$ & $22,6 \%$ & $37,7 \%$ & $11,3 \%$ & $100 \%$ \\
\hline \multicolumn{8}{|l|}{ Significance } \\
\hline & $\mathrm{r}=0.688$ & & & & & & \\
\hline
\end{tabular}

Additionally, there is significant positive correlation between the importance for journalists to stress the political, social and economic achievements of their own country and their freedom/ability to do so in their daily practice ( $\mathrm{p}=0.000$, $\mathrm{r}=0.728$ ). As Table 10 shows, $35,8 \%$ of the journalists believe it is extremely important, while an even higher percentage $(41,5 \%)$ is urged to do so in their daily practice. On the opposite scale only $3,8 \%$ considered that it is not common at all to do so in their daily practice while everybody agrees on their importance.

Table 10. Correlation between importance of stressing national achievements and ability to do so in daily practice

\begin{tabular}{|c|c|c|c|c|c|c|c|}
\hline & $\begin{array}{l}\text { Not } \\
\text { important at } \\
\text { all/ Not } \\
\text { common at al }\end{array}$ & $\begin{array}{l}\text { Not very } \\
\text { important/ Not } \\
\text { common }\end{array}$ & $\begin{array}{l}\text { Somewhat } \\
\text { important/ } \\
\text { Sometimes }\end{array}$ & $\begin{array}{l}\text { Very } \\
\text { important/ } \\
\text { Common }\end{array}$ & $\begin{array}{l}\text { Extremely } \\
\text { important/ } \\
\text { Very common }\end{array}$ & Missing cases & Total \\
\hline $\begin{array}{l}\text { Importance of } \\
\text { stressing the } \\
\text { political, social and } \\
\text { economic } \\
\text { achievements of } \\
\text { your own country }\end{array}$ & - & $3,8 \%$ & $17 \%$ & $34 \%$ & $35,8 \%$ & $9,4 \%$ & $100 \%$ \\
\hline $\begin{array}{l}\text { Being able to stress } \\
\text { the political, social } \\
\text { and economic } \\
\text { achievements of } \\
\text { your own country }\end{array}$ & $3,8 \%$ & $11,3 \%$ & $9,4 \%$ & $22,6 \%$ & $41,5 \%$ & $11,3 \%$ & $100 \%$ \\
\hline
\end{tabular}


Significance

$\mathrm{p}=0.000$

$\mathrm{r}=0.728$

Respectively, there is a significant positive correlation between the importance journalists' attribute to championing achievements of individuals and groups that belong to own country and their freedom/ability to do so in the news stories they are covering $(\mathrm{p}=0.000, \mathrm{r}=0.591)$. As Table 11 shows, championing national achievements in the news stories is a very common practice in the Cypriot national newspapers, since $39,6 \%$ of the journalists consider it extremely important, while $43,4 \%$ of them are urged to do so in their daily practice. And only $1.9 \%$ considers them not important as well as not common at all.

Table 11. Correlation between importance of championing achievements of individuals/groups that belong to own country and ability to do so in daily practice

\begin{tabular}{|c|c|c|c|c|c|c|c|}
\hline & $\begin{array}{l}\text { Not important } \\
\text { at all/ Not } \\
\text { common at al }\end{array}$ & $\begin{array}{l}\text { Not very } \\
\text { important/ Not } \\
\text { common }\end{array}$ & $\begin{array}{l}\text { Somewhat } \\
\text { important/ } \\
\text { Sometimes } \\
\end{array}$ & $\begin{array}{l}\text { Very } \\
\text { important/ } \\
\text { Common } \\
\end{array}$ & $\begin{array}{l}\text { Extremely } \\
\text { important/ } \\
\text { Very common }\end{array}$ & $\begin{array}{l}\text { Missing } \\
\text { cases }\end{array}$ & Total \\
\hline $\begin{array}{l}\text { Importance of } \\
\text { championing the } \\
\text { achievement of } \\
\text { individuals/ groups } \\
\text { that belong to own } \\
\text { country/locality in } \\
\text { the news coverage }\end{array}$ & $1,9 \%$ & $13,2 \%$ & $17 \%$ & $18,9 \%$ & $39,6 \%$ & $9,4 \%$ & $100 \%$ \\
\hline $\begin{array}{l}\text { Being able to } \\
\text { champion the } \\
\text { achievement of } \\
\text { individuals/ groups } \\
\text { that belong to own } \\
\text { country / locality in } \\
\text { the news coverage }\end{array}$ & $1,9 \%$ & $18,9 \%$ & $5,7 \%$ & $18,9 \%$ & $43,4 \%$ & $11,3 \%$ & $100 \%$ \\
\hline
\end{tabular}

Significance

$\mathrm{p}=0.000$

$\mathrm{r}=0.591$

The chi-square tests of independence show that there is significant dependence between what journalists believe it is important concerning championing national values and ideals and what they can actually write about national values and ideals in their news stories $\left(\mathrm{x}^{2}=43.143, \mathrm{df}=16, \mathrm{p}=0\right)$. As Table 12 shows, $35,8 \%$ of the journalists believe it is very important and $18,9 \%$ extremely important while a significant $41,5 \%$ is urged to do so in their daily practice. Table 12 also shows that only $1,9 \%$ of then state that it is not important at all, while 5,7\% do not use them in their daily practice. In this perspective, the statistical analysis shows that although journalists in general believe they should appear more balance in their news coverage, newspapers themselves urge them in championing national values and ideals.

Table 12. Correlation between journalists' beliefs about writing for national values/ideals and daily practice

\begin{tabular}{|c|c|c|c|c|c|c|c|}
\hline & $\begin{array}{l}\text { Not important } \\
\text { at al/Not } \\
\text { common at al }\end{array}$ & $\begin{array}{l}\text { Not very } \\
\text { important/Not } \\
\text { common }\end{array}$ & $\begin{array}{l}\text { Somewhat } \\
\text { important/ } \\
\text { Sometimes }\end{array}$ & $\begin{array}{l}\text { Very } \\
\text { important/ } \\
\text { Common }\end{array}$ & $\begin{array}{l}\text { Extremely } \\
\text { important/ } \\
\text { Very common }\end{array}$ & $\begin{array}{l}\text { Missing } \\
\text { cases }\end{array}$ & Total \\
\hline $\begin{array}{l}\text { Importance for } \\
\text { journalists to } \\
\text { champion national } \\
\text { values and ideals }\end{array}$ & $1,9 \%$ & $3,8 \%$ & $28,3 \%$ & $35,8 \%$ & $18,9 \%$ & $11,3 \%$ & $100 \%$ \\
\hline Common practice & & & & & & & \\
\hline
\end{tabular}




$\begin{aligned} & \text { for journalists to } \\ & \text { champion national } \\ & \text { values and ideals }\end{aligned}$
\[ \begin{array}{l}5,7 \% \\ \text { Significance }\end{array} \]
\[ \mathrm{x}^{2}=43.143, \mathrm{df}=16 \]

\section{Conclusions}

In their answers to our questionnaires, journalists and editors have revealed that they perceive it part of their journalistic rights, their ethical obligations and an integral component of their professional function, to promote and display patriotism and national achievements in their newspapers. In fact, reinforcing patriotism by exhibiting national achievements is a practice that, they claim, does not affect balanced reporting. Despite their claims, we find that the newspapers studied in our work do not display a profuse content of patriotic discourse or national achievements, certainly not to the degree that journalists and editors themselves seem to believe that they incorporated this practice in their publications. On the contrary, we find evidence that they carried out an effort to publish impartial stories.

We contend that our observation can, at least in part, be elucidated by the fact that the events examined here comprise an economic crisis rather than a national, political one. As such, the crisis did not only occur in Cyprus, and did not only affect Cypriot society. Rather, it was (and still is) in existence, and in various stages of severity, in several European nations, if not throughout the EU, then at least in the European south. Therefore, the journalists reporting on this crisis were not dealing with a matter of national survival or pride, and 'loud' patriotic discourse in their reportages might seem out of place. Furthermore, given that the sources used in the stories necessarily included European and international ones, we also claim that, to another degree, journalists may have attempted to practice balanced reporting, avoiding introspection and incorporating their work in a wider, European environment.

In this respect, we can conclude that patriotic discourse may be absent from stories not perceived to be about 'national matters' and urge the further investigation of this possibility. In this perspective, further research could be based on a qualitative study, regarding the content of the journalistic reportages of the specific newspapers examined. Since the content in this paper is examined in a quantitative basis, a qualitative study can offer useful results in the future, regarding the specific way(s) patriotism and national triumph are expressed, directly or/and indirectly.

\section{Acknowledgements}

This research is a part of the "Journalistic role performance around the Globe" research program. All data included in this article are national data concerning Cyprus.

\section{References}

Aday, S., Livingston, L. S., \& Herbert, M. (2005). 'Embedding the Truth: A Cross-cultural Analysis of Objectivity and Television Coverage of the Iraq War', Press/Politics, 10(1), 3-21.

Altheide, L. D. (2004). Consuming Terrorism. Symbolic Interaction, 27(3), 289-308.

Barber, B. (1996). Constitutional faith. In M. C. Nussbaum and J. Cohen (eds.), For Love of Country: Debating the Limits of Patriotism. Boston, MA: Beacon Press, 30-37.

Benedict, A. (1983). Imagined Communities: reflections on the origin and spread of Nationalism. London: Verso.

Billig, M. (1995). Banal Nationalism. London: Sage.

Coombs, W. T. (1999). Ongoing Crisis Communication: Planning, Managing and Responding. C.A.: Sage Thousand Oaks.

Downing, J. (2000). Radical Media. Rebellious communication and social movements.Thousand Oaks: Sage.

Eisman, A. (2003). 'THE MEDIA OF MANIPULATION: PATRIOTISM AND PROPAGANDA. Mainstream News in the United States in the Weeks Following'. Critical Quarterly, 45(1-2), 55-72.

Goddart, P., Robinson, P., \& Parry, K. (2008). 'Patriotism meets plurality: reporting the 2003 Iraq War in the British press', Media, War \& Conflict, 1(1), 9-30. http://dx.doi.org/10.1177/1750635207087623

Habermas, J. (1996). Between Facts and Norms. Cambridge: Polity Press.

Ignatieff, M. (1999). 'Benign nationalism? the possibilities of the civic ideal'. In E. Mortimer and R. Fine (eds.), People, 
Nation, and State: The Meaning of Ethnicity and Nationalism, 141-148.

Kellner, D. (2003). Media Spectacle. New York: Routledge.

Lewis, C. S. (2008). 'News, Nationalism, and the Imagined Communicty'. Journalism Studies, 9(3), $409-428$. http://dx.doi.org/10.1080/14616700801999212

Lewis, J., Brookes, R., Mosdell, N., \& Threadgold, T. (2006). Shoot First and Ask Questions Later: Media Coverage of the 2003 Iraq War. New York: Peter Lang.

Maniou, T. (2013). 'Traditional Media in Transition? The reliability of political news in the New Media Age'. Mediterranean e-journal of Communication and Media, 2(1), Available at http://mediaejournal.org/traditional-media-in-transition/

McQuail, D. (2006). 'Media Roles in Society. In N. Carpentier, P. P., Vengerfeldt, K., Nordenstreng, M., Hartmann, P. V., \& Cammaerts, B. (eds.), Researching Media, Democracy and Participation Tartu: Tartu University Press, 47-58.

Mellado, C. (2014). Professional Roles in News Content: Six dimensions of journalistic role performance. Journalism Studies, 1-19. http://dx.doi.org/10.1080/1461670x. 2014. 922276

Mellado, C., \& Lagos, C. (2014). 'Professional Roles in News Content: Analyzing Journalistic performance in the Chilean National Press'. International Journal of Communication, 8, 2090-2112.

Mellado, C., \& VanDalen, A. (2013). 'Between Rhetoric and Practice: Explaining the gap between role conception and performance in journalism'. Journalism Studies, 1-20. http://dx.doi.org/10.1080/1461670X.2013.838046

Moshe, M. (2004). 'Between National and Constitutional Patriotism: framing financial patriotic discourse'. Journalism Studies, 5(4), 497-509.

Moshe, M., \& Lehman-Wilzig, S. (2006). 'UNDER FIRE: Framing Classic and "New Patriotism” in Israel's Elite and Popular Press during the El-Aqsa Intifada and World Trade Center Terror Attacks'. In T. Pludowski (Ed.), Global Media Reactions to September 11. Media Coverage of the Attack and its Aftermath in Europe, Asia, Australia, and the US, 179-198. Spokane, WA: Marquette Books.

Nathanson, S. (1993). Patriotism, Morality, and Peace. Lanham: Rowman \& Littlefield.

Pawson, R. (1995). Methods of Content/Document/Media Analysis. In M. Haralambo (Ed.), Developments in Sociology, 107-128. Ormskirk: Causeway Press.

Press and Information Office (PIO) of the Cyprus government (ed.), (2000). Kv́ $\pi \rho \circ$ (Cyprus). Nicosia. (In Greek.)

Primoratz, I. (2015). 'Patriotism'. In Edward N. Zalta (ed.), The Stanford Encyclopedia of Philosophy (Spring 2015 Edition), http://plato.stanford.edu/archives/spr2015/entries/patriotism/.

PRIO group (ed.), (2010). Media Narratives, Politics and the Cyprus Problem. Nicosia: PRIO Cyprus Center.

Rorty, R. (1998). Achieving our Country: Leftist Thought in Twentieth-century America, Cambridge, MA: Harvard University Press.

Shabani, O., \& Payrow, A. (2002). 'Who's Afraid of Constitutional Patriotism? The binding source of citizenship in constitutional states'. Social Theory and Practice, 28(3), 419- 443.

Waisbord, S. (2002). Journalism, Risk and Patriotism In B. Zelizer \& S. Allan (eds.), Journalism after September, 11 201-219.

Yumul, A., \& Özkirimli, U. (2000). 'Reproducing the nation: "banal nationalism” in the Turkish press'. Media, Culture \&Society, 22(6), 784-804.

Zhang, Y. (2014). 'Analysing the connotation of Mao Zedong’s Nationalism'. International Journal of Social Sciences Studies, 2(1), 65-69. http://dx.doi.org/10.11114/ijsss.v2i1.242

\section{(cc) $\mathrm{Br}$}

This work is licensed under a Creative Commons Attribution 3.0 License. 